\title{
Effects of feeding varying levels of fufu sieviate meal based diets with Panicum maximum basal on the blood characteristics of West African dwarf goats.
}

\author{
Efectos de alimentar niveles variables de fufu se basan en las \\ dietas basadas en harina con Panicum maximum basal en las \\ características de sangre de las cabras enanas de África \\ occidental.
}

Peter-Damian Chukwunomso Jiwuba ${ }^{1}$, Ekeno Michael Assam² and Eka Christian Inyang ${ }^{3}$

1- Department of Animal Health and Production Technology, Federal College of Agriculture, P.M.B.7008, Ishiagu, Ebonyi State, Nigeria.

2- Department of Animal Science, Akwa Ibom State University, Akwa Ibom State, Nigeria.

3- Department of Animal Production Technology, Federal College of Agriculture, P.M.B.7008, Ishiagu, Ebonyi State, Nigeria

\section{ABSTRACT}

The effects of fufu sieviate meal based diets at $0 \%, 20 \%, 40 \%$ and $60 \%$ levels using Panicum maximum as the basal on the haematological and serum biochemical parameters of West African dwarf (WAD) goats were studied for 87 days. Thirty six blood samples were collected from the WAD goats and their haematological and serum biochemical indices were determined using Beckman Coulter AC-T10 Laboratory Haematology Blood Analyzer and Bayer DCA 2000+ HbA1c analyzer, respectively using a completely randomized design. Packed cell volume $(P C V)$ was better $(p<0.05)$ at $T_{1}$ than the other treatments. Red Blood Cell $(R B C)$ and mean corpuscular haemoglobin $(\mathrm{MCH})$ were numerically improved at $T_{2}, T_{3}$ and $\mathrm{T}_{4}$ than in the control group while lymphocyte increased significantly $(P<0.05)$ with increasing levels of the test ingredient. Results on serum biochemical indices showed that serum urea, creatinine, glucose and ALP differed significantly $(P<0.05)$ and tended to be higher in the treatment $\left(T_{2}, T_{3}\right.$ and $\left.T_{4}\right)$ groups than the control group. The study therefore revealed that inclusion of fufu sieviate in the diets of West African Dwarf goats had no deleterious effects on the haematological and serum biochemical parameters of WAD goats 
and could be included up to $60 \%$ in goat diets.

Keywords: Fufu sieviate, cassava root sieviate, haematology, serum chemistry, goats, WAD.

\section{RESUMEN}

Se estudiaron los efectos de las dietas basadas en harfu en dietas a niveles de $0 \%$, 20\%, 40\% y 60\% utilizando Panicum maximum como el basal en los parámetros hematológicos y bioquímicos séricos de las cabras enanas de África Occidental (WAD) durante 87 días. Se recogieron treinta y seis muestras de sangre de las cabras WAD y se determinaron sus índices hematológicos y bioquímicos séricos usando el analizador hematológico de laboratorio Beckman Coulter AC-T10 y el analizador Bayer DCA 2000+ $\mathrm{HbA1c}$, respectivamente, utilizando un diseño completamente aleatorizado. El volumen de células empaquetadas (PCV) fue mejor $(p<0,05)$ en T1 que en los otros tratamientos. Los glóbulos rojos (RBC) y la hemoglobina corpuscular media ( $\mathrm{MCH}$ ) se mejoraron numéricamente en T2, T3 y T4 que en el grupo de control, mientras que los linfocitos aumentaron significativamente $(P<0,05)$ con niveles crecientes del ingrediente de prueba. Los resultados en los índices bioquímicos séricos mostraron que la urea sérica, la creatinina, la glucosa y el ALP difirieron significativamente $(P<0.05)$ y tendieron a ser más altos en los grupos de tratamiento (T2, T3 y T4) que en el grupo de control. Por lo tanto, el estudio reveló que la inclusión del fufu sieviate en las dietas de las cabras enanas de África Occidental no tuvo efectos nocivos sobre los parámetros bioquímicos séricos y hematológicos de las cabras WAD y podría incluirse hasta en un $60 \%$ en las dietas de cabra. Palabras clave: Fufu sieviate, raíz de mandioca, hematología, química sérica, cabra, WAD.

\section{INTRODUCTION}

Recently, the cost of conventional energy feed resources have increased considerably owing to the competition by man and industries. These competition and hike in price of these conventional raw materials have intensified the need to find unconventional feed resource that can replace a percentage of these products in ruminant diets especially goats at a lower cost of production. Cassava (Manihot esculenta crantz) or its by-products usually come to mind in this respect because of its high calorie content and readily availability.

World cassava production has increased by $4.6 \%$ between 2013 and 2014 (FAO 2014); this output may be higher today due to higher demand for cassava and possible population growth. Cassava is majorly cultivated in Africa and Latin America for its starchy roots and ranks first as a staple food in Nigeria (Jiwuba and Ezenwaka 2016). Cassava is a 
hardy crop which require little inputs, has prolong underground storability and can be harvested to produce garri, fufu, tapioca, abacha, chips, starch, flour etc which are all in high demand in Nigeria. These numerous uses of the crop has led to its high demand for different human or industrial uses thereby enhancing the availability of the sieviate which are grossly underutilized and are hitherto discarded as waste (Jiwuba and Ezenwaka 2016). Cassava harvesting and processing produce large amounts (Fasae et al. 2015) of sieviate and are generally considered to contribute significantly to environmental problems when left in the surroundings of processing areas or carelessly disposed off. Cassava root sieviate constitutes about $25 \%$ of the whole plant (Aderemi and Nworgu 2007) and are usually discarded poorly as waste heaps near streams or homes where they are soaked, fermented and processed thereby producing a strong offensive smell and contaminations. However, fufu sieviate, if well processed, can be beneficial to livestock feeding. There is paucity of information on the utilization of this by-product as livestock feed, particularly in goat diets. The metabolizable energy value of cassava root meal is about $3,870 \mathrm{kcal} / \mathrm{kg}$ which is higher than that of maize $(3,430 \mathrm{kcal} / \mathrm{kg}$ ) (Tion and Adeka 2000). However, the low protein content (Salcedo et al., 2010), high cyanide content (Ubalua and Ezeronye 2008, Morgan and Choct 2016) and high fibre and moisture contents are among the limiting factor in the utilization of fufu sieviate. This study is therefore designed to determine the effects of different levels of fufu sieviate meal on the blood chemistry and haematological characteristics of WAD goats. Since there are known cases of antinutritional factors like HCN which can adversely affect the health status of animals, the blood studies becomes necessary to determine the effect of this on the blood parameters of the goats.

\section{MATERIALS AND METHODS}

The research work was carried out at sheep and goat unit of Federal College of Agriculture, Ishiagu, Ivo Local Government Area of Ebonyi State. The College is situated and longitude at Latitude $5.56^{\circ} \mathrm{N}$ and $7.31^{\circ} \mathrm{E}$, with an average rainfall of $1653 \mathrm{~mm}$ and a prevailing temperature condition of $28.50^{\circ} \mathrm{C}$ and relative humidity of about $80 \%$.

The fufu sieviate was sourced and harvested within Ishiagu and neighbouring communities. The fufu sieviate is a by product of cassava tuber. It is gotten after the cassava tubers meant for fufu production are peeled or not, washed clean and soaked in clean water for 3-5 days to ferment so as to reduce the hydrogen cyanide level and also to soften the tuber for sieving. Thereafter, the soaked cassava tuber are sieved, the sieviate collected and sundried for about 5 days to reduce the moisture contents and possible anti- 
nutrients that were not removed during the fermentation process. The sundried fufu sieviates were milled using hammer mill and later used in the formulation of the experimental diets.

Four diets $T_{1}, T_{2}, T_{3}$, and $T_{4}$, were formulated. The fufu sieviate meal was included at the levels of $0 \%, 20 \%, 40 \%$ and $60 \%$ for $T_{1}, T_{2}, T_{3}$, and $T_{4}$, respectively as presented in Table 1.

Table 1: Composition of the experimental diets

\begin{tabular}{lllll}
\hline \multirow{2}{*}{ Ingredients } & \multicolumn{3}{c}{ Dietary Level (\%) } \\
\cline { 2 - 4 } & $\mathrm{T} 1$ & $\mathrm{~T} 2$ & $\mathrm{~T}$ & T4 \\
\hline Fufu sieviate meal & 0.00 & 20.00 & 40.00 & 60.00 \\
Maize offal & 60.00 & 40.00 & 20.00 & 0.00 \\
Groundnut meal & 8.00 & 8.00 & 8.00 & 8.00 \\
Wheat offal & 27.50 & 27.50 & 27.50 & 27.50 \\
Bone meal & 2.00 & 2.00 & 2.00 & 2.00 \\
Limestone & 1.00 & 1.00 & 1.00 & 1.00 \\
Salt & 1.00 & 1.00 & 1.00 & 1.00 \\
Vitamin premix & 0.50 & 0.50 & 0.50 & 0.50 \\
\hline Total & 100 & 100 & 100 & 100
\end{tabular}

Thirty six (36) WAD goats of about 8 - 10 months of age were selected from the College herd for this experiment. The goats were randomly divided into 4 groups of 9 animals each with 3 goats constituting a replicate. The four treatments were assigned to the four experimental diets in a Completely Randomized Design (CRD). The animals were housed individually in well ventilated cement floored pens equipped with feeders and drinkers. Each animal received a designated treatment diet in the morning for 87 days. Feed offered was based on $3.5 \%$ body weight per day; the animals in addition were fed a $\mathrm{kg}$ wilted chopped Panicum maximum later in the day as basal diet to enhance rumination and chime chewing. Regular access to fresh drinking water was made available.

Five $\mathrm{ml}$ of blood sample was drawn from each animal on the last day of the study. The goats were bled through the jugular vein. The samples were separated into two lots and used for haematological and biochemical determinations. An initial $2.5 \mathrm{ml}$ was collected from each sample in labelled sterile universal bottle containing $1.0 \mathrm{mg} / \mathrm{ml}$ ethyldiamine 
tetracetic acid (EDTA) and used for haematological analysis. Another $2.5 \mathrm{ml}$ was collected over anti-coagulant free bottle and used for the serum biochemical studies. Serum biochemistry and haematological parameters will be measured using Beckman Coulter AcT10 Laboratory Haematology Blood Analyzer and Bayer DCA 2000+ HbA1c analyzer, respectively. Mean corpuscular haemoglobin $(\mathrm{MCH})$, mean corpuscular volume (MCV), mean corpuscular haemoglobin concentration (MCHC).

The results were statistically analyzed using the Statistical Package for Social Sciences Window 17.0. One-way analysis of variance (ANOVA) was employed to determine the means and standard error. Treatment means were compared using Duncan's new multiple range test (Duncan 1955).

\section{RESULTS AND DISCUSSION}

Table 2 presents the haematological parameters of West African dwarf goats fed varying levels of fufu sieviate meal. The PCV, RBC counts, $\mathrm{MCH}$ and lymphocyte were significantly influenced by the treatment diets while $\mathrm{Hb}, \mathrm{MCV}, \mathrm{MCHC}, \mathrm{WBC}$ count and neutrophil were not influenced $(p>0.05)$ by the diets. The PCV values in this study fell within the normal physiological range of $21.00-35.00 \%$ and $22.00-38.00 \%$ reported for clinically healthy WAD goats by Daramola et al. (2005) and Jiwuba et al. (2016). The significantly lower PCV values of the treatment animals (T2, T3 and T4) could be attributed to poor utilization of the diets or may be due to the possible case of anti nutritional factor like HCN which abound in cassava and its byproducts. The findings are in agreement with the results of Oni et al. (2017) who reported significant $(p<0.05)$ lower PCV values for WAD goats placed on supplemental cassava peels with cassava leaves and cowpea haulms. The results, however, disagrees with the reports of Jiwuba et al. (2016) who reported significantly $(P<.005)$ improved PCV values to WAD goats fed Pro-vitamin A cassava peel supplemental diets with Centrocema pubescens leaf meal. The RBC counts was significantly $(p<0.05)$ and numerically improved for T2 goats. The range of $10.52-13.11 \mathrm{~g} / \mathrm{dl}$ reported in this study are within the normal physiological range of $8-18\left(\times 10^{12} / \mathrm{I}\right)$ and 7.00 $21.00\left(\times 10^{6} / \mathrm{L}\right)$ reported for clinically healthy WAD goats by Oni et al. (2012) and Olaifa and Opara (2011) for WAD goat respectively and are comparable with the reported range of 9.9$14.8 \times 10^{12} / \mathrm{L}$ and $10.40-13.20\left(\times 10^{12} / \mathrm{I}\right)$ by Ajayi et al. (2012) and Oni et al. (2012) for WAD goats. The results of this study showed that the diets supported good health status of the goats, and hence the animals were not likely to suffer anemia-related diseases. The non 
significance $(p>0.05)$ of $\mathrm{Hb}, \mathrm{MCV}$ and $\mathrm{MCHC}$ has been previously reported by Oni et al. (2012) and Jiwuba et al. (2016) who fed cassava by products to WAD goats. This is an indication that the quality of the treatment diets was similar to that of the control diet, thus indicating that the nutritional quality of the diets was not compromised by the fufu sieviate meal. The $\mathrm{MCH}$ values in this study showed significant $(p<0.05)$ difference and fell within the reference range of 5.2-8.0pg for goats as reported by Fraser and Mays (1986) for goats. The normal range of $\mathrm{MCH}$ recorded in this study for the WAD goats gave a clear indication of the absence of anaemia among the experimental groups. The values obtained in this study for lymphocyte fell within the normal range of $47-82 \%$ and $50-70 \%$ reported by Daramola et al. (2005) and Jiwuba et al. (2016) for WAD goats. This thus suggested active immunity to ensure good health condition among the goats. In earlier studies (Ukanwoko and Ironkwe 2012, Oni et al. 2012) similar ( $p>0.05$ ) values were reported for WBC counts and Neutrophil for WAD goats fed different cassava by-products. This indicated that the diets supported the health condition of the goats.

Table 2: Haematological indices of WAD goats fed fufu sieviate meal based diets

\begin{tabular}{llllll}
\hline Parameters & $\mathrm{T}_{1}$ & $\mathrm{~T}_{2}$ & $\mathrm{~T}_{3}$ & $\mathrm{~T}_{4}$ & SEM \\
\hline PCV (\%) & $33.10^{\mathrm{a}}$ & $28.99^{\mathrm{b}}$ & $30.69^{\mathrm{b}}$ & $27.21^{\mathrm{b}}$ & 3.07 \\
$\mathrm{Hb}(\mathrm{g} / \mathrm{dl})$ & 8.71 & 9.91 & 7.83 & 8.73 & 0.41 \\
RBC (x10\%/L) & $10.52^{\mathrm{b}}$ & $13.11^{\mathrm{a}}$ & $12.07^{\mathrm{ab}}$ & $11.02^{\mathrm{b}}$ & 2.83 \\
MCV (fl) & 17.72 & 15.78 & 17.21 & 16.09 & 0.89 \\
MCH (pg) & $6.09^{\mathrm{b}}$ & $7.02^{\mathrm{a}}$ & $5.11^{\mathrm{c}}$ & $6.96^{\mathrm{a}}$ & 0.40 \\
MCHC (\%) & 30.09 & 31.61 & 29.92 & 31.21 & 2.41 \\
WBC (x10\%/UL ) & 8.01 & 7.15 & 9.40 & 8.33 & 0.52 \\
Lymphocyte (\%) & $59.79^{\mathrm{c}}$ & $63.14^{\mathrm{b}}$ & $62.48^{\mathrm{b}}$ & $65.31^{\mathrm{a}}$ & 5.00 \\
Neutrophil (\%) & 31.82 & 30.06 & 33.13 & 32.05 & 1.97 \\
\hline
\end{tabular}

a-c means in the row with different superscripts are significantly different $(p<0.05)$.

The total protein, AST and ALT showed no significant $(p>0.05)$ values; this indicating the safety of the treatment diets in maintaining protein and amino acid metabolism and better liver functioning of the animals. Urea, creatinine, glucose and ALP showed significant $(p<0.05)$ difference across the treatment groups (Table 3 ). The urea values of $3.68-4.86$ $\mathrm{mmol} / \mathrm{l}$ reported in this study fell within the reference range of $3.6-7.1 \mathrm{mml} / \mathrm{L}$ for goats reported by Fielder (2011) and were favourably compared with reported $3.67-4.18 \mathrm{mml} / \mathrm{L}$ and $3.3-4.2 \mathrm{mml} / \mathrm{L}$ for WAD goats fed Moringa oleifera leaf meal diets and ensiled mixtures 
of elephant grass (Pennisetum purpureum) with lima bean, African yam bean and pigeon pea as reported by Jiwuba et al. (2017) and Ajayi et al. (2012) respectively. The significantly high serum urea observed for the treatment groups is in comparison with the this control may be due to persistent hypoglycemia, thus resulting to high urea concentration. However, the within range reported in this study may indicate no kidney damage; since urea and creatinine concentrations are used as an index of renal function. Similarly, the range of $0.75-1.03 \mathrm{mg} / \mathrm{dl}$ reported for creatinine in this present fell within the normal range $(0.7-1.5 \mathrm{mg} / \mathrm{dl})$ for apparently healthy goats as reported by Fraser and Mays (1986) suggested the quality of the diets were not compromised by the fufu sieviate. The blood glucose values ranged between 2.83 and $3.73 \mathrm{mmol} / \mathrm{L}$ are within the range of 2.7 $4.2 \mathrm{mmol} / \mathrm{L}$ for goats reported by Aiello (2000). The superior glucose value observed for T4 in comparison with other treatments may be attributed to the higher energy value of cassava root meal. The higher blood glucose values exhibited by the goats in this study were indicative of their nutrient status. The serum enzymes (AST, ALT and ALP) are used as indicator of hepatic damage, bile obstruction and bone formation. The non significance $(p>0.05)$ of AST and ALT and within the normal physiological ranges for all the enzymes studied in this study for goats suggested that no liver damage occurred among the experiment goats. This result is in agreement with the finding of Jiwuba et al. (2016) indicating the high quality of fufu sieviate for not causing liver damage.

Table 3: Blood chemistry of WAD goats fed fufu sieviate meal based diets

\begin{tabular}{llllll}
\hline Parameters & \multicolumn{1}{c}{$\mathrm{T}_{1}$} & \multicolumn{1}{c}{$\mathrm{T}_{2}$} & $\mathrm{~T}_{3}$ & \multicolumn{1}{c}{$\mathrm{T}_{4}$} & SEM \\
\hline Total Protein (mmol/l) & 7.70 & 6.85 & 7.01 & 7.09 & 0.34 \\
Urea (mmol/l) & $3.68^{\mathrm{b}}$ & $4.72^{\mathrm{a}}$ & $4.65^{\mathrm{a}}$ & $4.86^{\mathrm{a}}$ & 0.48 \\
Creatinine (mg/dl) & $0.81^{\mathrm{b}}$ & $0.90^{\mathrm{ab}}$ & $1.03^{\mathrm{a}}$ & $0.75^{\mathrm{b}}$ & 0.16 \\
Glucose (mmol/l) & $2.83^{\mathrm{b}}$ & $2.97^{\mathrm{b}}$ & $3.42^{\mathrm{ab}}$ & $3.73^{\mathrm{a}}$ & 0.19 \\
AST (U/L) & 17.04 & 19.02 & 17.23 & 19.51 & 1.14 \\
ALT (U/L) & 18.82 & 17.07 & 18.87 & 16.93 & 1.01 \\
ALP (U/L) & $77.17^{\mathrm{d}}$ & $82.97^{\mathrm{c}}$ & $92.72^{\mathrm{a}}$ & $89.49^{\mathrm{b}}$ & 5.12
\end{tabular}

${ }^{a-d}$ means in the row with different superscripts are significantly different $(p<0.05)$.

In conclusion, this study has shown that fufu sieviate meal had no detrimental effect on haematological and serum biochemical parameters of WAD goats and therefore could be included in the diets of West African Dwarf goats up to $60 \%$. 


\section{ACKNOWLEDGEMENTS}

The authors are grateful to the Department of Animal Production Technology, Federal College of Agriculture, Ishiagu, for providing the goats, and facilities used in this study.

\section{REFERENCES}

Aderemi, F.A., \& Nworgu F.C. 2007. Nutritional status of cassava peels and root sieviate biodegraded with Aspergillus niger. American-Eurasian J. Agric. and Environ. Sci. 2: 308-311.

Aiello, S.E. 2000. The Merck Veterinary Manual. 8th ed. Merck \& Co., Inc, White House, N.J., U.S.A.

Ajayi, F.T., Ogunleke F., Adesina A., \& Durotoye E.S. 2012. Performance, haematology and serum biochemistry of West African Dwarf Goats fed ensiled mixtures of elephant grass (Pennisetum purpureum) with lima bean, African yam bean and pigeon pea. Kasetsart. J. Nat. Sci. 46: $694-702$.

Daramola, J.O., Adeloye A.A., Fatoba T.A., \& Soladoye A.O. 2005. Haematological and Biochemical parameters of WAD goats. Livestock Research for Rural Development. 17: www. Cipav.org.co/Irrd.

Duncan, D.B. 1955. Multiple New Range and multiple F - Test. Biometrics, 11: 1- 42.

FAO (Food and Agriculture Organization of the United Nations). 2014. Food Outlook. Biannual report on global food markets.

Fasae, O.A., Amos A.O., Owodunni A., \& Yusuf A.O. 2015. Performance, Haematological Parameters and Faecal Egg Count of Semi-intensively Managed West African Dwarf Sheep to Varying Levels of Cassava Leaves and Peels Supplementation. Pertanika J. Trop. Agric. Sci. 38: $71-81$.

Fielder SE. 2011. Serum Biochemical Reference Ranges. Merck \& Co., Inc., Kenilworth, NJ, USA. 2011.

Fraser, C. M., \& Mays A. 1986. The Merck Veterinary Manual. A handbook of diagnosis, therapy and disease prevention and control for the Veterinarian. Sixth Edition. Merck \& Co., Inc. Rahway, New Jersey, USA. 905-908.

Jiwuba, P.C., Ahamefule F.O., Ogbuewu I.P., \& Ikwunze K. 2017. Blood chemistry and 
haematology of West African Dwarf goats fed Moringa oleifera leaf meal (MOLM) in their diets. Comp. Clin. Pathol. 26: 621-624.

Jiwuba, P.C., \& Ezenwaka L.C. 2016. Growth performance and apparent nutrient digestibility of West African dwarf goats fed yellow root cassava peel-centrosema leaf meal based diets. Case Stud. J., 5: 204 - 210.

Jiwuba, P.C.,. Ezenwaka L.C, Ikwunze K., \& Nsidinanya N.O. 2016. Blood profile of West African Dwarf goats fed provitamin A cassava peel-centrosema leaf meal based diets. Analele Stiintifice ale Universitatii,, Alexandru Ioan Cuz", Sectiunea Genetica si Biologie Moleculara TOM XVII, Fascicula 3: 27-134.

Morgan, N.K., \& Choct M. 2016. Cassava: Nutrient composition and nutritive value in poultry diets. An. Nutr. 2: 253-261.

Olaifa, A. K., \& Opara M.N. 2011. Haematological and biochemical parameters of West African Dwarf (WAD) bucks castrated by the burdizzo method. Vet. Archiv 81: 743750.

Oni, A.O., Abatan A., Adebayo K., Sowande O.S., Iposu S., \& Onwuka C.F.I. 2017. Effects of supplementing cassava peels with cassava leaves and cowpea haulms on the rumen environment and blood profile parameters of West African dwarf goats. Arch. Zootec. 66: 395-402.

Oni, A.O., Arigbede O.M., Sowande O.S., Anele U.Y., Oni O.O., Onwuka C.F.I., Onifade O.S., Yusuf K.O., Dele P.A., \& Aderinboye R.Y., 2012. Haematological and serum biochemical parameters of West African Dwarf goats fed dried cassava leaves-based concentrate diets. Trop Anim Health Prod. 44: 483-490.

Salcedo, A., Valle A.D., Sanchez B., Ocasio V., Ortiz A., Marquez P., \& Siritunga D. 2010. Comparative evaluation of physiological post-harvest root deterioration of 25 cassava (Manihot esculenta) accessions: visual vs. hydroxycoumarins fluorescent accumulation analysis. African J. Agricult. Res., 5: 3138 - 3144.

Tion, M. A., \& Adeka I. 2000. Evaluation of cassava root meal as a replacement for maize in broiler diets. Pages: 19 - 23. In: Ukachukwu, S. N., Ibeawuchi, J. A., Ibe, S. N., Ezekwe A. G. and Abasiekong, S. F. (Eds.) Proceedings of 25th Nigerian Society for Animal Production Annual Conference. Michael Okpara University of Agriculture, Umudike, Abia State, Nigeria.

Ubalua, A.O., \& Ezeronye O.U. 2008. Growth Responses and Nutritional Evaluation of Cassava Peel Based Diet on Tilapia (Oreochromis niloticus) Fish Fingerlings. J. Food Technol., 6: 207-213. 
Sustainability, Agri, Food and Environmental Research (ISSN: 0719-3726), 6(1), 2018: 1-10

http://dx.doi.org/10.7770/safer-V6N1-art1316

Ukanwoko, A.I., \& Ironkwe M.O. 2012. Growth Performance and Haematological Values of West African Dwarf (WAD) Goats Fed Leucaena, Gliricidia and Cassava Leaf Meal Cassava Peel Based Diets. International Research Journal of Agricultural Science and Soil Science 2: 98-101.

Received: $10^{\text {th }}$ November 2017

Accepted: $13^{\text {th }}$ March 2018 